\title{
KAUNO MEDICINOS UNIVERSITETO STUDENČIŲ FIZINIO PAJĖGUMO KAITA
}

\author{
Algė Vitartaitė, Laimonas Šiupšinskas, Vincas Bieliūnas, Ričardas Liachovičius, \\ Liutauras Plioplys, Ernesta Sendžikaitė, Gerardas Šauklys \\ Kauno medicinos universitetas, Kaunas, Lietuva
}

\begin{abstract}
Algė Vitartaitė. Biomedicinos mokslų daktarè. Kauno medicinos universiteto Kineziologijos ir sporto medicinos katedros docentė. Moksliniu tyrimų kryptis — žmogaus funkcinių galimybių diagnostika ir adekvačių jo būklei poveikių tyrimas.
\end{abstract}

\section{SANTRAUKA}

Studentu fizinio pajėgumo komponentu juvertinimas leidžia nustatyti tiriamojo fizinę būklę, stebèti jos kaita taikant pasirinktas fizinio aktyvumo formas, sudaryti individualias sveikatos stiprinimo programas.

Tyrimo tikslas — nustatyti Kauno medicinos universiteto studenčiu fizinio pajégumo kaita 1994-2004 metais (2001 m. tyrimas nebuvo atliktas). Tiriamaji kontingenta sudare 1569 Kauno medicinos universiteto pirmo kurso studentes (amžiaus vidurkis - 18,66 \pm 0,03 metu). Iš ju 139 studentès pakartotinai testuotos ketvirtais studiju metais. Jos buvo suskirstytos i dvi grupes: sportuojančiuju ir nesportuojančiuju. Fizinis pajégumas nustatytas taikant Eurofito testus. Tyrimai parodè, kad per dešimties metu laikotarpi Kauno medicinos universiteto pirmo kurso studenčiu bendrosios ištvermés, pilvo raumenu ištvermès, plaštakos jègos, šuolio į tolị, vikrumo ir greitumo rezultatai blogëja. Ypač ryškus fiziniu ypatybiu išugdymo prastëjimas pastebètas 2003 ir 2004 m. Studiju metais sportuojančiu merginu lankstumas, pilvo raumenu ištvermé gerèjo, plaštakos jèga mažèjo, o kitu fiziniu ypatybiu išugdymo lygis išliko stabilus. Nesportuojančiu studenčiu fizinis pajėgumas studiju metais prastëjo. Sportuojančiu ketvirto kurso studenčiu sveikatai svarbiu fiziniu ypatybiu rodikliai buvo daug geresni nei fiziškai pasyviu.

Raktažodžiai: fizinis pajėgumas, fizinis aktyvumas, studenčiu sveikata.

\section{IVADAS}

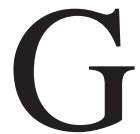
era sveikatos būklè yra pagrindinè prielaida socialiniam, ekonominiam ir asmens vystymuisi bei svarbi gyvenimo kokybės sudètinė dalis. Sveikata suprantama kaip pagrindinių organizmo funkcinių sistemų rezervinių galimybių visuma, ì kurią turi būti įtraukta ne tik esama funkcinè organizmo būklè, bet galimybè reguliuoti ir pagerinti ją. Tokia holistinè sveikatos samprata pagrista kur kas didesne paties žmogaus atsakomybe už savo sveikata, kuri net
$50 \%$ priklauso nuo gyvenimo būdo (Sveikata 21, 2000). Nors daugumos studentų požiūriu sveikata yra svarbiausia vertybė, tačiau ju gyvensenos tyrimų duomenys rodo, kad tarp deklaruojamo teigiamo požiūrio ị būtinumą rūpintis savo sveikata ir rizikos veiksniu paplitimo yra didelis skirtumas (Kardelis ir kt., 2001; Kriaučionienė, 2001). Palyginus paskutinių metǔ šalies aukštosiose mokyklose studijuojančiujų sveikatos tyrimų rezultatus (Kardelis ir kt., 2001; Škemaitè, 1999) 


\begin{tabular}{|c|c|c|c|c|c|c|c|c|c|c|c|}
\hline \multirow{2}{*}{$\begin{array}{l}1 \text { lentelè. KMU pir- } \\
\text { mo kurso studenčiu } \\
\text { skaičiaus skirstinys }\end{array}$} & Metai & 1994 & 1995 & 1996 & 1997 & 1998 & 1999 & 2000 & 2002 & 2003 & 2004 \\
\hline & $\begin{array}{l}\text { I kurso } \\
\text { studentės }\end{array}$ & 109 & 167 & 172 & 48 & 146 & 168 & 164 & 82 & 210 & 303 \\
\hline
\end{tabular}

su analogiškais ankstesnių tyrimų duomenimis (Varatinskienè, 1993) matyti, kad tarp studentu plinta svaigalų ir rūkalų vartojimas, mažejja fizinis aktyvumas. Tyrimų duomenys byloja, kad $41 \%$ studentų vaikinų ir 64\% merginų fizinis aktyvumas yra nepakankamas (Tamošauskas ir kt., 2003). Taip pat pastebèta, kad tarp fiziškai aktyvių studentų mažiau paplitę rizikos veiksniai, jie geriau vertina sveikatą ir rečiau skundžiasi dèl psichosomatinių negalavimų nei fiziškai pasyvūs bendraamžiai (Petkevičienė ir kt., 2002). Per visą mokymosi aukštojoje mokykloje laikotarpi nustatyti teigiami sportavusių studentų širdies ir kraujagyslių sistemos reakcijos ị krūvius pokyčiai, geresni ir kiti funkciniai rodikliai. Pabrèžiama, kad geras fizinis pajègumas aktyvina fiziologinius procesus, lemiančius greitesni organizmo prisitaikymą prie besikeičiančių sąlygų. Ryšiai tarp sveikatos, kasdienio fizinio aktyvumo ir fizinio pajègumo yra kompleksiški. Fiziniam pajègumui priskiriami požymiai, kuriuos veikia kasdienis fizinis aktyvumas ir kurie yra susiję su sveikata (Eurofitas, 2003).

Šiuolaikinės universitetinės studijos išsiskiria gausiu informacijos srautu, mokymo proceso intensyvejjimu, padidejjusiais reikalavimais specialistu rengimo kokybei. Tai sudaro ypatinga psichoemocinę itampa, taip pat didina studentų sveikatos patologinių nukrypimų galimybę. Todèl aktualia moksline problema ir toliau lieka studentu gyvensenos ypatumu, funkcinio ir fizinio pajejgumo vertinimas, sveikatos ugdymo bei fizinio aktyvumo programų rengimas.

Tyrimo tikslas - nustatyti Kauno medicinos universiteto studenčių fizinio pajègumo kaita 1994-2004 metais.

Uždaviniai:

1. Nustatyti Kauno medicinos universiteto pirmo kurso studenčių fizinio pajègumo ypatumus per dešimties metų laikotarpi.

2. Ivertinti studenčių fizinio pajègumo rodikliu pokyčius studijų metais.

3. Palyginti sportuojančių ir nesportuojančių studenčių fizinio pajègumo rodiklius.

\section{TIRIAMUUJŲ KONTINGENTAS IR TYRIMO METODAI}

Tiriamaji kontingentą sudarè 1569 Kauno medicinos universiteto Medicinos, Odontologijos ir Slaugos fakulteto pirmo kurso studentès (amžiaus vidurkis - 18,66 $\pm 0,03$ metu). Iš ju 139 studentès pakartotinai testuotos ketvirtais studijų metais. Jos buvo suskirstytos i dvi grupes: sportuojančiuju ir nesportuojančiujų. Sportuojančiu grupę $(\mathrm{n}=18)$ sudarè studentès, nurodžiusios, kad laisvalaikiu per paskutinius dvejus studijų metus kasdien, keletą arba du kartus per savaitę mankštinasi mažiausiai 1 valandą. Studentės, kurios mankštinasi keletą kartų per mėnesi ar dar rečiau, priskirtos nesportuojančiu grupei $(n=121)$.

Nustatant fizini pajėguma, buvo taikyti šie Eurofito testai: flamingo pusiausvyros, tepingo, plaštakos suspaudimo, šuolio ị toli iš vietos, „Sèstis ir siekti“, „Sèstis ir gultis“, $10 \times 5$ m bègimo šaudykle ir ištvermès bėgimo (Kineziologijos pagrindai, 2004).

Tyrimo duomenų analizė atlikta naudojant SPSS 13 programa. Buvo apskaičiuojamas aritmetinis vidurkis, standartinis nuokrypis, aritmetinio vidurkio paklaida, priklausomų ir nepriklausomų imčių vidurkio skirtumų reikšmingumas - pagal Stjudento $t$ kriterijų. Vidurkių skirtumas laikytas patikimu, jei paklaidos tikimybė mažesnė nei 0,05 .

\section{REZULTATAI}

Kauno medicinos universiteto pirmo kurso studenčių fizinio pajègumo rezultatų kaita pateikta $1-8$ paveiksle. Tyrimo rezultatai parode, kad flamingo pusiausvyros geriausi rezultatai užfiksuoti paskutiniais metais, t. y. 2003 ir 2004 m. (atitinkamai 7,83 $\pm 0,33$ ir 8,20 $\pm 0,26$ karto). Prasčiausią pusiausvyros rezultatą studentès parode 1997 m. - 12,5 \pm 0,77 karto (1 pav.). Vertinant tiriamujų tepingo testo rezultatus pastebèta, kad 1994-2002 m. rankos judesio greitis svyravo nuo 11,2 iki 11,6 s. Didžiausia šio rodiklio reikšmè nustatyta $2003 \mathrm{~m} .-12,11 \pm 0,09 \mathrm{~s}$ (2 pav.). 
2 lentelè. Sportuojančiųjų ir nesportuojančiųjų fizinio pajègumo komponentų kaita studijų metais

\begin{tabular}{|c|c|c|c|c|c|c|c|c|c|}
\hline Tiriamuju grupè & $\begin{array}{l}\text { Tyrimo } \\
\text { laikas }\end{array}$ & $\begin{array}{l}\text { Flamingo } \\
\text { testas, } \\
\text { kartai / min }\end{array}$ & $\begin{array}{l}\text { Tepingo } \\
\text { testas, } \mathrm{s}\end{array}$ & $\begin{array}{c}\text { Plaštakos } \\
\text { suspaudimas, } \\
\text { kg }\end{array}$ & $\begin{array}{l}\text { Šuolis } \mathfrak{i} \text { toli, } \\
\mathrm{cm}\end{array}$ & $\begin{array}{l}\text { „Sėstis ir } \\
\text { gultis“, } \\
\text { kartai / } 30 \mathrm{~s}\end{array}$ & $\begin{array}{l}10 \times 5 \mathrm{~m} \\
\text { bègimas } \\
\text { šaudykle, } \mathrm{s}\end{array}$ & $\begin{array}{c}\text { „Sèstis ir } \\
\text { siekti“, cm }\end{array}$ & $\begin{array}{l}\text { Bendroji } \\
\text { ištvermé, } \\
\text { min }\end{array}$ \\
\hline \multirow{3}{*}{$\begin{array}{l}\text { Nesportuojančios } \\
\text { studentės } \\
(\mathrm{n}=121)\end{array}$} & I kurse & $11 \pm 0,57$ & $11,19 \pm 0,09$ & $33,41 \pm 0,53$ & $173,1 \pm 1,7$ & $23,8 \pm 0,43$ & $20,75 \pm 0,18$ & $28,4 \pm 0,63$ & $5,25 \pm 0,13$ \\
\hline & IV kurse & $7,91 \pm 0,56$ & $11,18 \pm 0,09$ & $28,14 \pm 0,63$ & $172,08 \pm 1,64$ & $23,18 \pm 0,47$ & $20,95 \pm 0,15$ & $28,46 \pm 0,63$ & $4,22 \pm 0,14$ \\
\hline & $\begin{array}{l}\text { Klaidos } \\
\text { tikimybė p }\end{array}$ & $\mathrm{p}<0,0001$ & $\mathrm{p}>0,05$ & $\mathrm{p}<0,0001$ & $\mathrm{p}>0,05$ & $\mathrm{p}<0,05$ & $\mathrm{p}>0,05$ & $\mathrm{p}>0,05$ & $\mathrm{p}<0,0001$ \\
\hline \multirow{3}{*}{$\begin{array}{l}\text { Sportuojančios } \\
\text { studentės } \\
(\mathrm{n}=18)\end{array}$} & I kurse & $8,56 \pm 1,55$ & $11,11 \pm 0,20$ & $34,71 \pm 1,40$ & $177,94 \pm 4,22$ & $24,65 \pm 1,30$ & $20,27 \pm 0,40$ & $31,32 \pm 1,6$ & $6,45 \pm 0,45$ \\
\hline & IV kurse & $7,19 \pm 1,08$ & $11,10 \pm 0,21$ & $31,63 \pm 1,72$ & $182,35 \pm 3,71$ & $27,06 \pm 1,12$ & $19,91 \pm 0,30$ & $33,68 \pm 1,54$ & $6,44 \pm 0,34$ \\
\hline & $\begin{array}{l}\text { Klaidos } \\
\text { tikimybė p }\end{array}$ & $\mathrm{p}>0,05$ & $\mathrm{p}>0,05$ & $\mathrm{p}<0,05$ & $\mathrm{p}>0,05$ & $\mathrm{p}<0,05$ & $\mathrm{p}>0,05$ & $\mathrm{p}<0,05$ & $\mathrm{p}>0,05$ \\
\hline
\end{tabular}

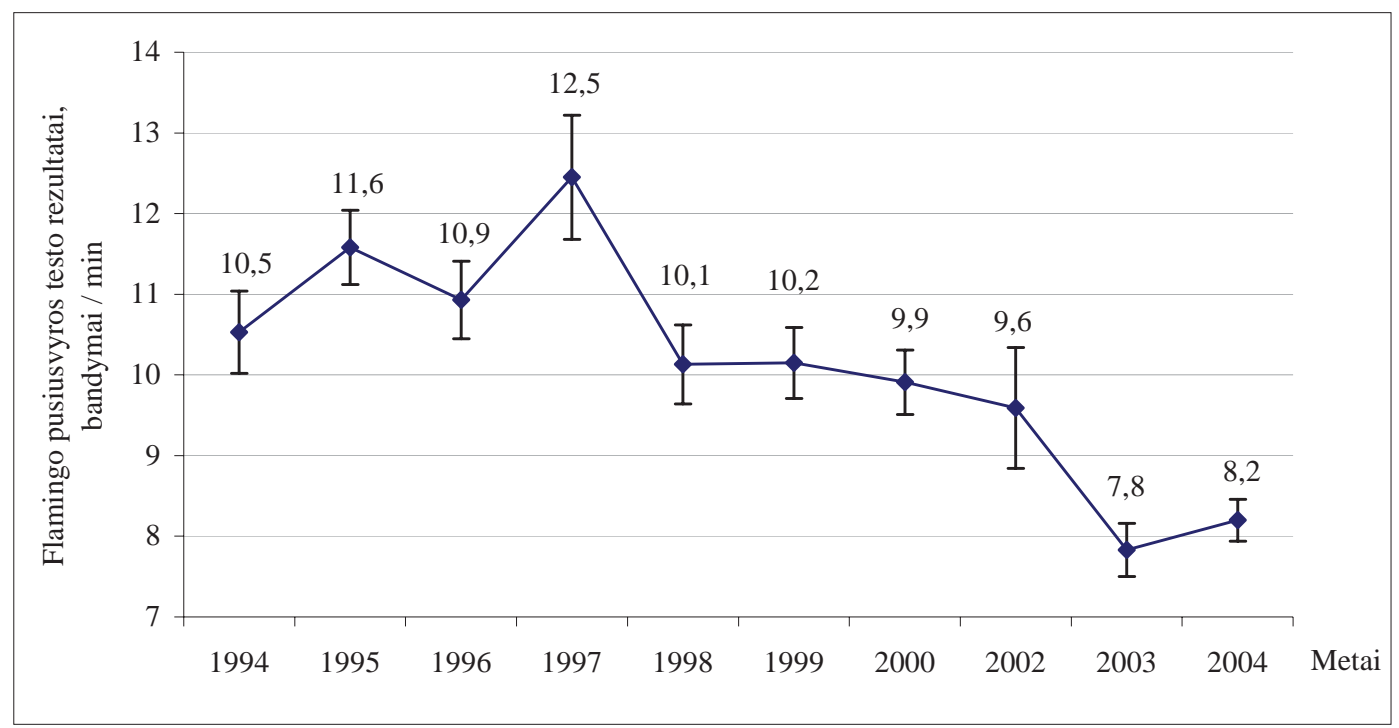

1 pav. Pirmo kurso studenčių pusiausvyros testo rezultatu kaita

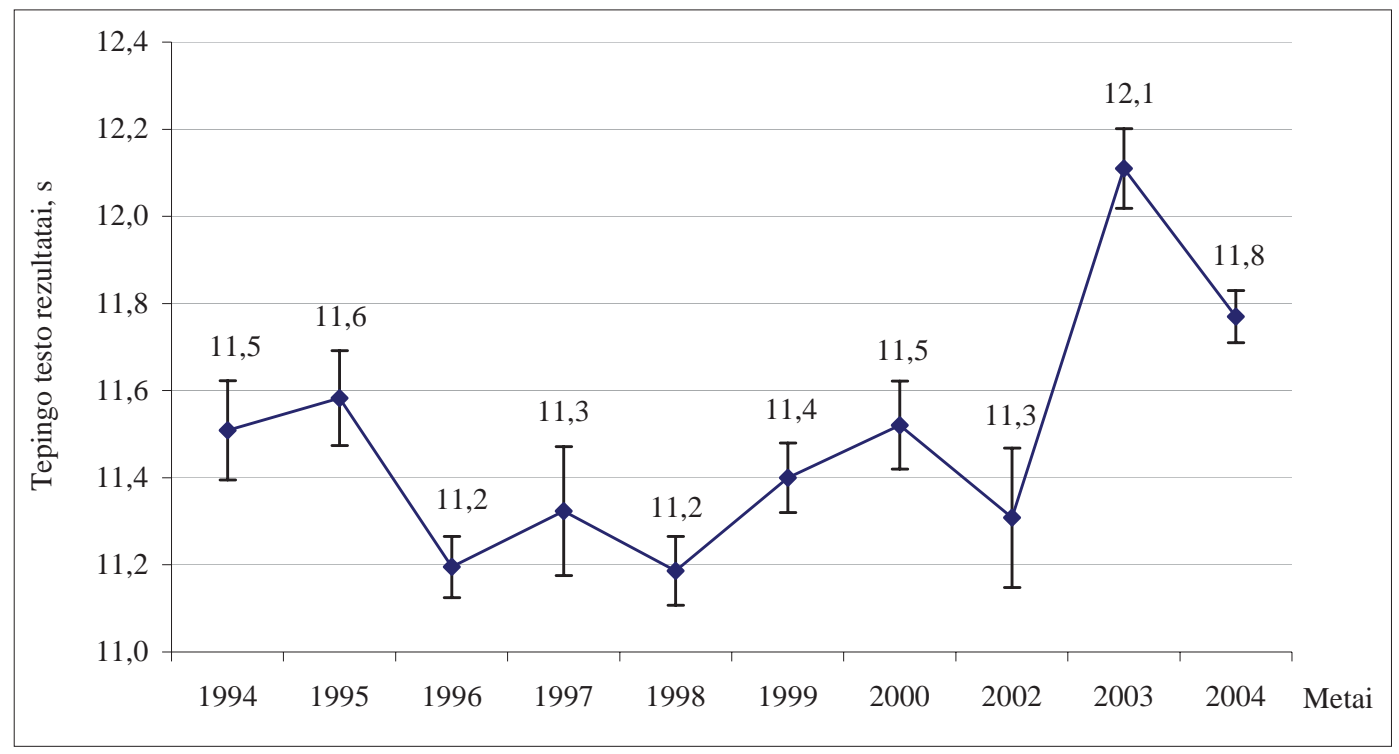

2 pav. Tepingo testo rezultatų kaita

Nors paskutinių metu tepingo testo rezultatai mažèjo (11,8 \pm 0,07 s), tačiau statistiškai patikimas ( $<$ 0,05) skirtumas, lyginant su 1994-2002 m., liko. Kaip matyti iš 3 paveikslo, studenčiu plaštakos jègos rezultatu vidurkiai 1994-1997 m. buvo panašūs ir svyravo nuo 34,1 iki 34,4 kg. Nuo 

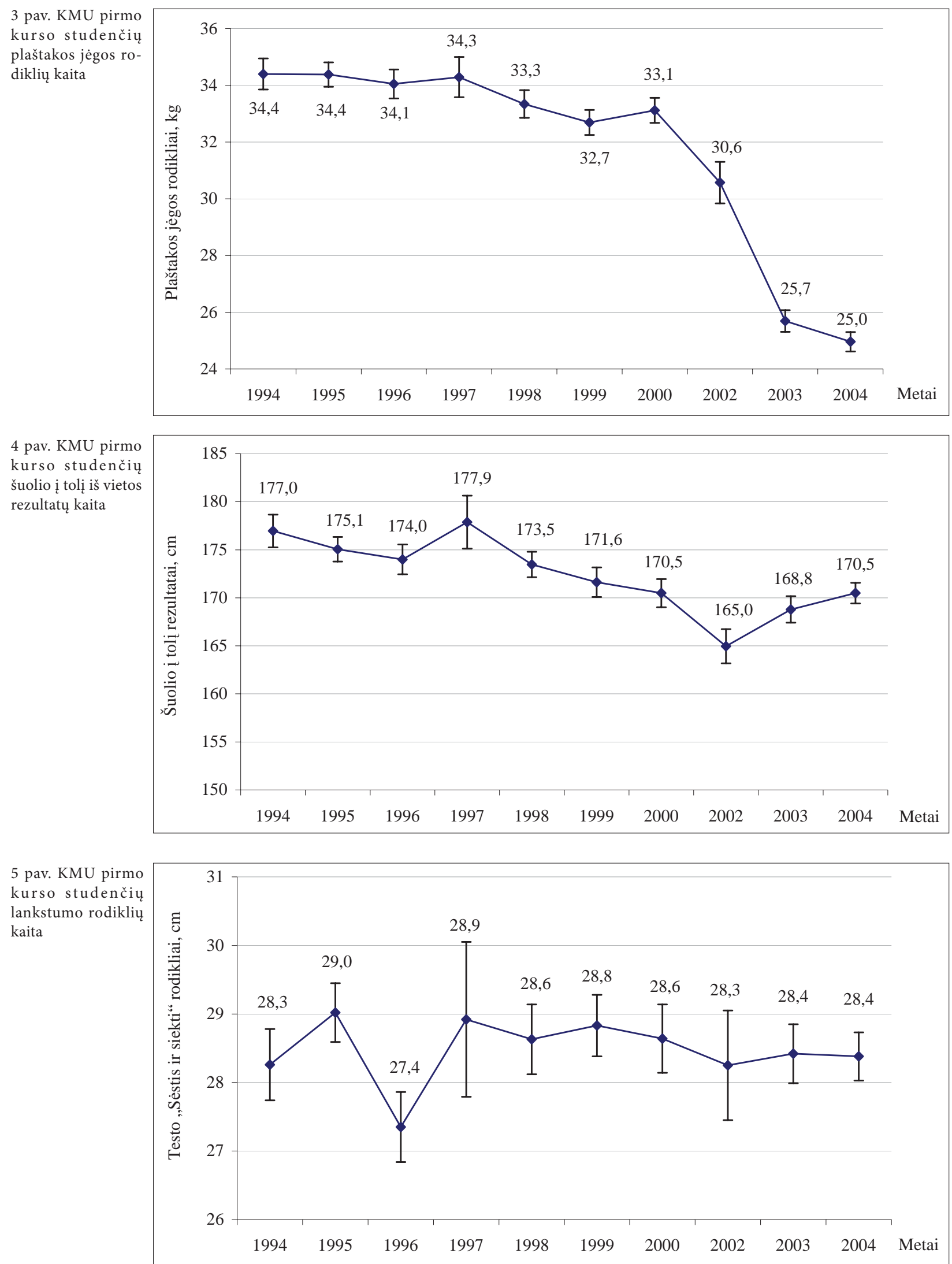

1998 m. pastebima šio rodiklio rezultatų mažèjimo tendencija, o nuo 2000 m. — statistiškai reikšmingi $(\mathrm{p}<0,05)$ rezultatų pokyčiai. $2004 \mathrm{~m}$. užregistruota absoliučiai mažiausia plaštakos jègos -
$25,0 \pm 0,34 \mathrm{~kg}$. Vertinant šuolio į toli rezultatus, pastebima tolygi vidurkių mažejimo kaita (4 pav.). Jei 1994 m. KMU studenčiu šuolio į tolį rezultatų vidurkis buvo $177 \pm 1,70 \mathrm{~cm}$, tai $2004 \mathrm{~m}$. - 


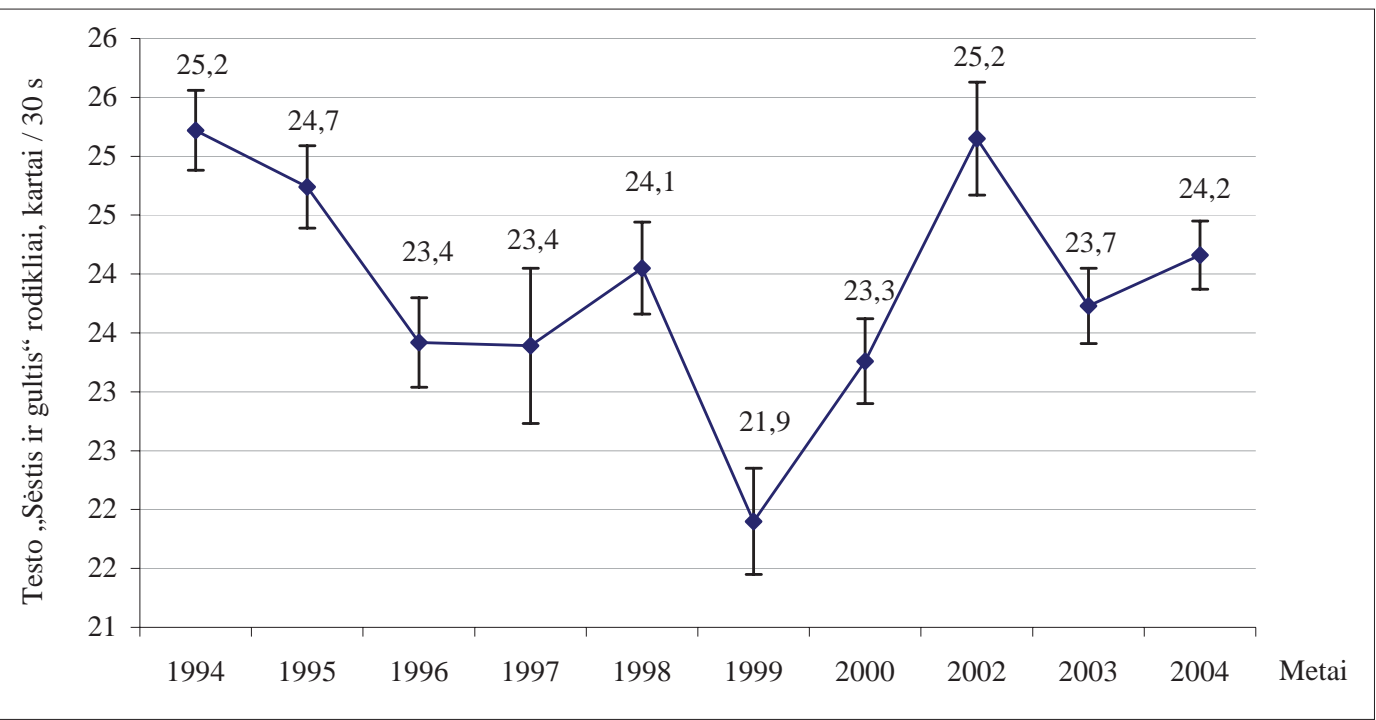

6 pav. KMU pirmo kurso studenčių pilvo raumenų ištvermès rodiklių kaita
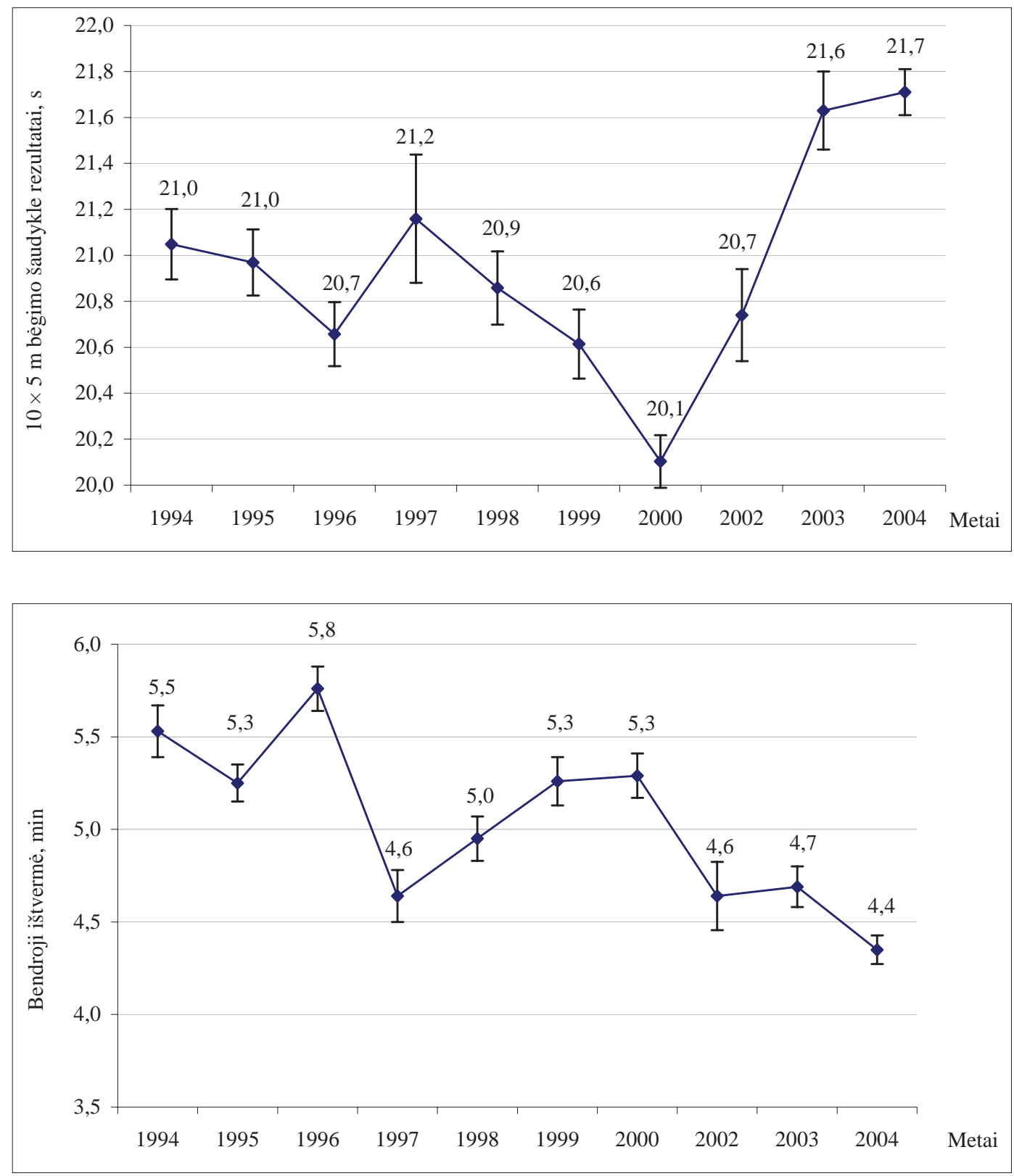

7 pav. KMU pirmo kurso studenčių vikrumo rezultatu kaita

8 pav. KMU pirmo kurso studenčių bendrosios ištvermès rezultatų kaita 
$170,5 \pm 1,07 \mathrm{~cm}$. Geriausias testo „Sèstis ir siekti““ rezultatas pasiektas $1995 \mathrm{~m}$. $-29,0 \pm 0,43 \mathrm{~cm}$, blogiausias $1996 \mathrm{~m} .-27,4 \pm 0,51 \mathrm{~cm}$ (5 pav.). Tuo tarpu kitų metu pirmakursių lankstumo rodikliai buvo panašūs. Testo „Sèstis ir gultis“ rezultato vidurkis $1994 \mathrm{~m}$. - 25,2 \pm 0,34 karto. Nuo 1995 m. nagrinèjamo rodiklio rezultatai smuko, o 1999 m. užregistruotas prasčiausias, t. y. 21,9 \pm 0,45 karto. Nors 2002 m. pakartotas geriausias testo „Séstis ir gultis“ rezultatas 25,2 \pm 0,48 karto, tačiau 2003 ir 2004 m. vèl nustatytas akivaizdus $(\mathrm{p}<0,05)$ rezultatu mažejjimas (6 pav.). Tyrimo duomenys parodè, kad nuo $1997 \mathrm{~m} .10 \times 5 \mathrm{~m}$ bègimo šaudykle rezultatai gerèjo, o nuo $2000 \mathrm{~m}$. - reikšmingai prastèjo (7 pav.). Blogiausi rezultatai užregistruoti 2003 ir 2004 m., atitinkamai $-21,6 \pm 0,17$ ir 21,7 $\pm 0,1 \mathrm{~s}$. Iš 8 paveikslo matyti, kad ištvermingiausios buvo $1996 \mathrm{~m}$. studentės $-5,8 \pm 0,12 \mathrm{~min}$, o paskutiniu metu (2004 m.) studentès parodè absoliučiai blogiausią rezultatą $-4,4 \pm 0,08 \mathrm{~min}$.

2 lentelèje pateikti ketvirtais studijų metais atlikto pakartotinio fizinio pajègumo testavimo duomenys. Flamingo pusiausvyros rezultatu reikšmingas pokytis nustatytas tik nesportuojančių studenčių grupejje $(p<0,05)$. Tuo tarpu sportuojančiu merginu grupèje buvo pastebima pusiausvyros vidurkio mažèjimo tendencija ( $p>0,05)$. Palyginus abieju grupių flamingo testo duomenis tiek pirmame, tiek ketvirtame kurse, statistiškai patikimo skirtumo neužregistruota $(p>0,05)$. Vertinant studenčių tepingo testo rezultatus pirmais ir ketvirtais studiju metais, statistiškai patikimo skirtumo nei tarp sportuojančių, nei tarp nesportuojančių merginų nenustatyta $(p>0,05)$. Nors plaštakos statinè jèga per ketverius studijų metus reikšmingai sumažèjo abiejose tiriamųjų grupèse $(p<0,05)$, tačiau statistiškai patikimai didesné ji buvo sportuojančių studenčiu grupejje. Pirmais studijų metais atlikus fizinio pajėgumo testavimą, abiejų grupių tiriamujų šuolio į tolị rezultatai buvo panašūs $(p>0,05)$. Po pakartotinio testavimo pastebetos skirtingos koju raumenu staigiosios jëgos kitimo tendencijos: sportuojančiu studenčiu grupejje - didejjo, nesportuojančiu — mažèjo ( $p>0,05)$. Antro tyrimo metu šuolio į tolį rezultatų vidurkis sportuojančiu grupejje buvo 183,35 $\pm 3,71 \mathrm{~cm}$, nesportuojančiu - 172,08 $\pm 1,64 \mathrm{~cm}$. Skirtumas statistiškai patikimas $(\mathrm{p}<0,05)$. Pirmame kurse testo „Sèstis ir gultis“ rezultatai abiejose grupèse buvo panašūs. Rezultatų pokyčio analizė parodè, kad studijų metais pilvo raumenu ištvermè nesportuojančiu grupejje mažèjo ( $\mathrm{p}<0,05)$, o sportuojančiu — didèjo $(\mathrm{p}<0,05)$. Vertinant lankstumo duomenis, nustatytas statistiškai patikimas abieju grupių rodikliu vidurkiu skirtumas antro tyrimo metu $(p<0,05)$. Jei nesportuojančių studenčiu lankstumo rezultatai per studijų laikotarpi nekito ( $p>0,05)$, tai sportuojančiu — reikšmingai padidèjo ( $\mathrm{p}<0,05) .10 \times 5 \mathrm{~m}$ bėgimo šaudykle rezultatai abiejose tiriamujų grupėse kito nedaug. Jau pirmo tyrimo metu bendrosios ištvermès rezultatų vidurkis reikšmingai $(\mathrm{p}<0,05)$ skyrèsi: sportuojančiu $-6,45 \pm 0,45 \mathrm{~min}$, nesportuojančiu $-5,25 \pm 0,13$ min. Pakartotinio tyrimo metu sportuojančių merginų ištvermès rezultatai išliko nepakitę (6,44 $\pm 0,34 \mathrm{~min})$, nesportuojančių — blogejo $(4,22 \pm 0,14 \mathrm{~min} ; \mathrm{p}<0,05)$.

\section{REZULTATŲ APTARIMAS}

Vertinant tyrimo rezultatus pastebėta, kad studenčių fizinių ypatybių rodikliai kiekvienais metais blogejja. Prastejja ne tik judamieji gebejjimai, tokie kaip greitumas (tepingo testas) ir vikrumas (10 × 5 m bėgimas šaudykle), kurie nèra itin reikšmingi ligu profilaktikai, bet ir su sveikata susijusios fizinès ypatybès. Teigiama, kad aerobinis pajègumas yra svarbiausias su sveikata susijusio fizinio pajègumo rodiklis (Kineziologijos pagrindai, 2004; Eurofitas, 2003). Remiantis atliktais tyrimais galima teigti, kad i Kauno medicinos universitetą kasmet įstoja vis mažesnio aerobinio pajègumo studentès. Pirmakursių merginų ištvermès rezultatų mažèjimo tendencijas patvirtina ir kitų Lietuvos aukštujų mokyklų studentų fizinio pajėgumo tyrimai (Jurgutienè ir kt., 2002). Analizuojant kitos su sveikata susijusios ypatybès - lankstumo - rezultatus, buvo pastebima nedidelè rezultatų kaita.

Nors manoma, kad galūnių raumenų pajègumas nèra tiesioginis sveikatos rodiklis, tačiau pakankama rankų ir koju jèga bei ištvermè yra būtinybẻ kasdieniame gyvenime. Raumenu jègą parodančiu testų - plaštakos suspaudimo ir šuolio i toli — rezultatai turèjo tendenciją mažèti. Atlikus pirmo kurso studenčių fizinio pajègumo duomenu analizę, nustatytas tik pusiausvyros rezultatu gerejjimas. Tokias studenčių fizinio pajègumo mažèjimo tendencijas galima paaiškinti nepakankamu fiziniu aktyvumu. V. Kriaučionienès tyrimų duomenimis (2001), pastebimas fiziškai pasyvių studentų skaičiaus didejjimas. 2-3 kartus 
per savaitę sportuojančių studentų $1998 \mathrm{~m}$. buvo 40\%, 2001 m. - 33\%. Nepakankamai fiziškai aktyvių merginų per šį laikotarpi padaugèjo 7,6\%, vaikinu - 12,2\%.

Per studiju laikotarpi pastebima nesveika akademinio jaunimo gyvensena, didejjantis sergamumas ir nuovargis, emocinès ir fizinès problemos (Raj et al., 2000). Tarp aukštesniuju kursų studentu ypač paplitęs fizinis pasyvumas. Mokslininkų duomenimis, pirmame kurse fiziškai pasyviu yra pusè, o penktame - jau du trečdaliai (Varatinskienè, 1993). Šiuos pastebèjimus papildo ir mūsų tyrimo duomenys, kurie parode fiziškai neaktyvių studenčiu funkciniu galimybiu mažèjimą studiju metais. Lyginant fizinio pajègumo testavimo rezultatus pirmais ir ketvirtais studiju metais nustatyta, kad nesportuojančių merginų plaštakos jèga, pilvo raumenų ištvermè ir bendroji ištvermè reikšmingai sumažèjo, pusiausvyros rezultatai pagerèjo, o vikrumo ir kojų raumenų staigiosios jègos rodikliai turèjo tendenciją blogèti. Tuo tarpu sportuojančių studenčių grupèje išryškejjo pusiausvyros, kojų raumenų staigiosios jègos, vikrumo rezultatu gerejjimo tendencija, lankstumo ir pilvo raumenų ištvermès statistiškai patikimi teigiami pokyčiai. Bendrosios ištvermès rodikliai fiziškai aktyvių studenčių grupèje nekito. Gauti tyrimo rezultatai patvirtina fizinio aktyvumo ir fizinio pajègumo ryši. Žmogaus kasdienis fizinis aktyvumas turi itakos fiziniam pajègumui, o pastarasis savo ruožtu veikia fizinį aktyvumą: didejjant pajègumui, žmogus paprastai yra aktyvesnis, o didesnis aktyvumas turi teigiamą poveikị pajègumui (Eurofitas, 2003).

Idomu tai, kad sportuoti labiau linkusios didesnio $(\mathrm{p}<0,05)$ aerobinio pajègumo merginos. Kitais fizinio pajejgumo komponentais pirmo tyrimo metu abieju grupių studentès nesiskyrè. Tačiau ketvirtais studijų metais sportuojančiu grupejje šeši iš aštuonių testų rezultatai buvo reikšmingai geresni nei fiziškai neaktyvių. Reikètų atkreipti dėmesi i tai, kad sportuojančios merginos nebuvo didelio meistriškumo sportininkès ir turèjo skirtingų pomėgių: vienos lankẻ sveikatingumo aerobikos treniruotes, kitos pasirinko sportinius žaidimus ar ciklinius pratimus.

1994-2004 metais sukaupti tyrimo duomenys ir darbo patirtis parode, kad naudojant Eurofito testų rinkini galima įvertinti konkretaus tiriamojo fizinio pajègumo trūkumus ir privalumus, jis gali būti taikomas atskiru grupių, kursų, fakultetu studentų testavimo rezultatams palyginti. Fizinio pajègumo testų rezultatų analizè gali padèti sudaryti studentų sveikatos ugdymo programas, individualizuoti fizinị krūvị, o ją papildžius žiniomis apie fizini aktyvumą ir gyvenimo būdo ypatumus - suvokti holistinę sveikatos sampratą.

\section{IŠVADOS}

1. Nustatyta, kad per dešimties metų laikotarpi Kauno medicinos universiteto studenčių pusiausvyros rezultatai gerejo, o lankstumo rodikliai išliko stabilūs. Bendrosios ištvermès, pilvo raumenų ištvermès, plaštakos jègos, šuolio i toli, vikrumo ir greitumo duomenų kaita rodo rezultatų blogejjimo tendencijas. Ypač akivaizdus fizinių ypatybių rodiklių prastėjimas pastebètas 2003 ir $2004 \mathrm{~m}$.

2. Studijų metais sportuojančių merginų lankstumas, pilvo raumenų ištvermė gerèjo, plaštakos jèga mažèjo, o kitų fizinių ypatybių išugdymo lygis išliko stabilus. Nesportuojančių studenčių fizinis pajègumas studijų metais prastėjo.

3. Sportuojančių ketvirto kurso studenčių sveikatai svarbių fiziniu ypatybių rodikliai buvo kur kas geresni nei fiziškai pasyvių. Pusiausvyros ir rankos judesio greičio rodikliai abiejose grupèse buvo panašūs.

\section{LITERATŪRA}

Eurofitas. Fizinio pajégumo testai ir metodika. Lietuvos studentu fizinio pajègumo rezultatai. (2003). Sud. V. Volbekienè. Vilnius: LSIC. P. 109.

Jurgutiené, A., Minkevičius, R., Gedminas, A. ir kt. (2002). Lietuvos veterinarijos akademijos I kurso studenčių fizinio pajègumo ịvertinimas. Ugdymas. Kūno kultūra. Sportas, 4 (45), 31-38.

Kardelis, K., Misevičienė, I., Šaferis, V. (2001). Studentu gyvensena ir požiūris i sveikatos stiprinimą. Ugdymas. Kūno kultūra. Sportas, 2 (39), 22-26.

Kineziologijos pagrindai. (2004). Mokomoji knyga. Sud. J. Poderys. Kaunas. P. 282.

Kriaučionienè, V. (2001). KMU ir KTU studentu sveikatos, gyvensenos ir gyvenimo kokybès ivertinimas: magistro baigiamasis darbas. Kaunas: KMU.

Petkevičienè, J., Kardelis, K., Misevičienė, I., Petrauskas, 
D. (2002). Kauno aukštujų mokyklų studentų fizinio aktyvumo, žalingu ipročių ir studijų krypties sąsaja. Ugdymas. Kūno kultūra. Sportas, 4 (45), 77-83.

Raj, S. R., Simpson, C. S., Hopman, W. M., Singer, M. A. (2000). Health related quality of life among final-year medical students. Canadian Medical Association Journal, 4, 162.

Sveikata 21. (2000). Sveikata visiems XXI. Pagrindiniai PSO visuomenės sveikatos priežiūros principai Europos regione. Vilnius: Lietuvos Respublikos sveikatos apsaugos ministerija.
Škėmaitė, J. (1999). Sveikos gyvensenos programos poreikio tyrimas ir planavimas aukštojoje mokykloje: magistro diplominis darbas. Kaunas.

Tamošauskas, P., Règalienė, G., Mačys, A. (2003). Studentu fizinio ugdymo teorijos ir metodikos pagrindai. Vilnius. P. 168.

Varatinskienè, R. (1993). Kauno aukštuju mokyklu studentu sveikata ir gyvensenos ypatumai: daktaro disertacija. Kaunas: KMU.

\title{
CHANGES IN PHYSICAL FITNESS OF FEMALE STUDENTS OF KAUNAS UNIVERSITY OF MEDICINE
}

\author{
Algė Vitartaitė, Laimonas Šiupšinskas, Vincas Bieliūnas, Ričardas Liachovičius, \\ Liutauras Plioplys, Ernesta Sendžikaitė, Gerardas Šauklys \\ Kaunas University of Medicine, Kaunas, Lithuania
}

\begin{abstract}
The assessment of physical fitness gives us a possibility to evaluate the functional state of a person. It allows to observe changes in physical fitness and use the proper form of physical activity, helps to compile health strengthening programs.

The aim of the research was to describe changes in physical fitness of female students of Kaunas University of Medicine in 1994-2004. We have assessed 1569 first year female students of Kaunas University of Medicine (age average $-18.66 \pm 0.03$ ). 139 of them were tested for the second time in the fourth year of studies. These female students were divided into two groups: physically active and not physically active. Physical fitness was assessed by the European tests of physical fitness - Eurofit. The results showed that the physical fitness of the first year female students was getting worsen every year of the testing. The students, who were physically active, got better flexibility, endurance of abdomen muscles. Other features of physical fitness were stable. The physical fitness of physically inactive female students got worsen during the testing period. The level of health-related physical fitness in the physically active female students of the fourth study year was significantly higher than that of the physically inactive students.
\end{abstract}

Keywords: physical fitness, physical activity, female students’ health.

Gauta 2005 m. sausio 31 d.

Received on January 31, 2005

Priimta 2005 m. birželio 30 d. Accepted on June 30, 2005
Algè Vitartaitè

Kauno medicinos universitetas

(Kaunas University of Medicine)

M. Jankaus g. 2, LT-50275 Kaunas

Lietuva (Lithuania)

Tel +370 37730580

E-mail algevita@gmail.com 